\section{THE MEDICO-PSYCHOLOGICAL CLINIC.}

To the Editor of THE LANCET.

SIR, - I am instructed by the medical committee of the proposed Medico-Psychological Clinic to inform you that the notice which appeared in the Observer of July 13th, giving a report of a private meeting held in connexion with the proposed clinic and asking for subscriptions to the same, was not inserted either with the knowledge or sanction of the committee, and the committee wish it understood that when details of the scheme they have in hand are ready for publication these details will be given in the first instance to THE LANCET and to the British Medioal Journal, and not to any non-professional papers. They regret that this notice has got into the lay press before the medical press had been communicated with.

I am, Sir, yours faithfully,

J. TURNER, Hon. Secretary.

Endsleigh-street, W.C., July 14th, 1913.

\section{THE LADIES' PLATE AT HENLEY REGATTA. \\ To the Editor of THE LANCET.}

SiR,- Justifiable exceptions have been taken by fathers whose sons are at public schools (Eton perhaps excepted, on account of their special advantages) to the fact that the boys are allowed to compete on equal terms for the Ladies' Plate at Henley Regatta with College eights who are year older and much more developed. Such efforts must be injurious to the growing lad on physical grounds. When consulted by parents on this subject I invariably advise them not to allow their boys to compete in such an unequal contest.

I am, Sir, yours faithfully,

Harrogate, July 11th. 1913. SHEPHERD BOYD

\section{MEMORIAL TO THE LATE DR. GEORGE ALEXANDER GIBSON.}

To the Editor of THE LANCET.

SIR,-Friends of the late Dr. George Alexander Gibson will be pleased to learn that the recent appeal for a fund to establish a "Gibson Memorial Lectureship" has already met with a most gratifying response.

A meeting of those subscribers who have intimated that they wish to join the general committee of the Memorial Fund will be convened some time in October. After this the subscription list will be closed, and a copy, together with the resolutions of the general committee, will be sent to each subscriber.

In case there may be any of the late Dr. Gibson's friends who did not receive an intimation and who might desire to subscribe, I may add that the honorary treasurer of the Memorial Fund is Mr. A. Gray Muir, W.S., 19, York-place, Edinburgh.-I am, Sir, yours faithfully,

\section{GEORGE A. BerRY,}

Convener of the Executive Committee.

31, Drumsheugh-gardens, Edinburgh, July 9th, 1913.

\section{A CORRECTION}

To the Editor of THE LANCET.

SIR,-You were good enough to publish in your issue of July 5th an article in which I described the remarkable travels of a cæcum. May I point out that my skiagram was printed upside down and so presented the unfortunate viscus cutting Father William-like capers on its head, the one vagary of which it was actually not guilty.

1 am, Sir, yours faithfully,

Wimpole-street, W., July 7th, 1913. IVOR BACK.

\section{THE LYMPHATICS OF THE LARGE INTESTINE. \\ To the Editor of THE LANCET.}

Sir, - We notice that in the Cavendish lecture lately delivered by Sir Berkeley Noynihan and published in THE LANCET of July 5th, it is assumed that all or almost all the investigations on the lymphatics of the large intestine were carried out on the foetus. In the paragraph dealing with the lymphatics accompanying the middle colic artery the words " in the foetuses examined by Jamieson and Dobson" give the impression that we used this kind of material only.

May we draw attention to a statement in the opening paragraph of our paper in the Annals of Surgery, to which reference is made in the lecture: "Our material was drawn from subjects of all ages-chiefly children and young adults -as, except in the case of the appendix, fotal specimens are not very satisfactory."

Of the 25 specimens of cæcum and appendix examined, 12 were foetal, and the age of the oldest subject was 61 years; of the 23 specimens of colon, 3 were fœtal, and the age of the oldest subject was 54 .

We are, Sir, yours faithfully,

J. KAX JAMrESON,

Leeds, July 9th, 1913

J. F. DOBSon.

\section{A MEDICAL TRADE UNION. To the Editor of THE LANCET.}

SiR,-The National Medical Guild, a trade union for medical practitioners with branches in all parts of the United Kingdom, will open temporary offices at 13, old Steine, Brighton, from July 18th to 26th next. An official of the Guild will be in attendance to explain the principles of trade union organisation as they affect the profession. There will be accommodation for such members of the Guild as may desire to hold small informal meetings.

I am, Sir, yours faithfully,

Percy C. RaIment, General Secretary.

34, Villiers-street, Strand, W.C., July 15th, 1913.

\section{THE NEED FOR RESEARCH IN TUBERCULOSIS \\ To the Editor of THE LANCET.}

SIR,-Your leading article on the Need for Research in Tuberculosis (May 10th) is most timely. The worst of the present state is that on such guesswork and conjecture as you describe, and ornamental pathology as Dr. Ewart puts it, legislation and popular rules leading to interference with liberty, ostracism, and unnecessary pain are based, the sufferers being lumped together as infective, whether trained (i.e., against scattering bacilli) or ignorant. And let it not be forgotten it is a pretty large minority whose freedom the campaigners are narrowing.

We medical readers know how to take medical writings and their contradictions, and we make allowances for the cocksureness of certain doctors, but the public cannot discriminate. They are given peptonised headlines by the antituberculosis pundits; they will be told the spray of an apparently bealthy but really tuberculous person, in the mere act of speaking, will carry hundreds of bacilli 10 feet, possibly straight into the listener's lung; and they will be confidently assured that "the only way we can prevent spray infection is by keeping people in acute infective states isolated ..... making them stop at home." But nothing is said of the recent testing, with negative results, of the telephones used by consumptives. There is more éclat in the physiologist's picture. It has thus come about that the popular attitude (thanks to the military sternness of the campaigners-destroy your enemy wherever you find him, and as soon as possible) towards the consumptive, which used to be one of kindness, pity, and sympathy, is now one of coldness and abhorrence, verging on the lethal chamber. A person with a cough is scowled at, the appearance of a spitting-bottle would disperse a meeting, a hostess will hesitate about asking a trained consumptive to tea, and the hotel manager boldly advertises "No consumptives," although in past times his business might have been built up with consumptives' gold. Your caution, therefore, against false conclusions should be taken to heart by associations and campaign people; reliable investigation on all points and re-investigation of old-accepted truths by modern methods are required before social restrictions and unnecessary pain are inflicted on the sensitive and harassed consumptive, who is suffering from no fault of his own, and who has contributed largely to the world's mental possessions, while the syphilitics and gonorrboals are flourishing and multiplying without interference.

I am, Sir, yours faithfully,

July 5th, 1913
RALLENTANDO 